\title{
Gebelikte Tütün Dumanı Maruziyetinin Anne Sıçan Böbrek Dokusunda Meydana Getirdiği Değişiklikler Üzerine Alfa Lipoik Asitin Etkilerinin Incelenmesi*
}

\author{
Elif ERDEM GÜZEL ${ }^{1 a \bowtie}$, Nalan KAYA ${ }^{2 b}$, Gonca OZAN KOCAMÜFTÜOĞLU ${ }^{3 c}$, Dürrin Özlem \\ DABAK $^{2 d}$, Penbe Sema TEMIZER OZAN ${ }^{3 e}$, İbrahim Enver OZAN ${ }^{2 f}$
}

1. Mardin Artuklu Üniversitesi, Sağlık Bilimleri Fakültesi, Ebelik Bölümü, Mardin, TÜRKiYE.

2. Fırat Üniversitesi, Tıp Fakültesi, Histoloji ve Embriyoloji Anabilim Dalı, Elazığ, TÜRKiYE.

3. Fırat Üniversitesi, Veteriner Fakültesi, Biyokimya Anabilim Dalı, Elazığ, TÜRKIYE.

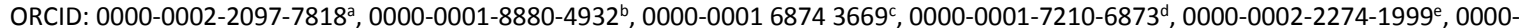
$0002-7274-5138^{f}$

\begin{tabular}{lcc}
\hline $\begin{array}{c}\text { Geliş Tarihi/Received } \\
\text { 21.03.2018 }\end{array}$ & $\begin{array}{c}\text { Kabul Tarihi/Accepted } \\
07.10 .2018\end{array}$ & Yayın Tarihi/Published \\
& & \\
\hline Bu makaleye atıfta bulunmak için/To cite this article: & & \\
Erdem Güzel E, Kaya N, Ozan Kocamüftüoğlu G, Dabak Dö, Temizer Ozan PS, Ozan iE: & Gebelikte Tütün Dumanı \\
Maruziyetinin Anne Sıçan Böbrek Dokusunda Meydana Getirdiği Değişiklikler Üzerine Alfa Lipoik Asitin Etkilerinin \\
Incelenmesi. Atatürk Üniversitesi Vet. Bil. Derg., 14(1): 52-63, 2019. DOI: 10.17094/ataunivbd.407782 \\
\hline
\end{tabular}

Öz: Çalışmada gebelikte tütün dumanına maruz kalan anne sıçanların böbrek dokusunda meydana gelen histopatolojik sonuçlar üzerine Alfa lipoik asitin etkilerinin deneysel olarak araştırılması amaçlandı. 28 adet dişi Sprague-Dawley cinsi sıçan kullanıldı. Gebe sıçanlar; Kontrol grubu, Tütün dumanı (TD) grubu, Tütün dumanı + Alfa lipoik asit (TD+ALA) grubu ve Alfa lipoik asit (ALA) grubu olmak üzere rastgele dört eşit gruba ayrıldı. TD ve TD+ALA grubundaki sıçanlar çiftleşmeden önce sekiz hafta ve gebelik süresince günde iki saat tütün dumanına maruz bırakıldı. TD+ALA ve ALA grubundaki sıçanlara ise çiftleşmeden önce sekiz hafta ve gebelik süresince gün aşırı gavaj yolu ile $20 \mathrm{mg} / \mathrm{kg}$ ALA verildi. Deney sonunda çıkarılan böbrek dokuları histolojik, immünohistokimyasal ve MDA düzeyi tayini metotları kullanılarak incelendi. TD grubuna ait böbrek kesitlerinde inflamatuar hücre artışı, Bowman boşluğunda artış, tübül lümeninde hiyalin birikimi gibi histopatolojik bulgulara rastlandı. ALA uygulaması ile histopatalojik bulguların büyük bir çoğunluğunda azalma gözlendi. TD grubunda VEGF immünreaktivitesinin kontrol grubuna göre anlamlı artış gösterdiği, TD+ALA grubunda ise TD grubuna göre anlamlı derecede azaldığı belirlendi. MDA seviyelerinde ise TD grubunda, kontrol grubuna göre anlamlı artış olduğu tespit edildi. Sonuç olarak, gebelik boyunca tütün dumanı maruziyetinin böbrek dokularında histopatolojik hasara ve damarlanmada artışa neden olduğu, ALA'nın ise bu etkilere karşı kısmen koruma sağladığı belirlendi.

Anahtar Kelimeler: Alfa Lipoik Asit, Böbrek, Gebelik, Sıçan, Tütün Dumanı.

\section{Investigation of the Effects of Alfa Lipoic Acid on Changes in Maternal Rat Kidney Caused by Tobacco Smoke Exposure in Pregnancy}

Abstract: The aim of this study was to investigate the effects of alpha lipoic acid on histopathological results of kidney tissue of mothers exposed to tobacco smoke during pregnancy. Twenty-eight Spraque-Dawley female rats were used. Rats were randomly divided into four groups: control, tobacco smoke (TS), tobacco smoke + alpha lipoic acid (TS+ALA) and alpha lipoic acid (ALA). Rats in the TS and TS+ALA groups were exposed to TS twice a day for one hour starting from eight weeks before mating and during pregnancy. $20 \mathrm{mg} / \mathrm{kg}$ of ALA was administered by gavage to ALA and TS+ALA group. The kidney tissues were examined by histological, immunohistochemical and MDA levels. Histopathological findings such as inflammatory cell increase, enlargement Bowman distance and hyaline casts in the tubule lumen were observed in the TS group. ALA application was found to reduce the majority of histopathological findings. VEGF immunoreactivity was significantly increased in the TS group compared to the control group, whereas in the TS+ALA group, VEGF immunoreactivity was significantly lower than TS group. MDA levels were significantly increased in the TS group compared to the control group. As a result, it has been shown that exposure of tobacco smoke during pregnancy causes an increase in histopathologic damage and vascularity in kidney tissues and that alpha lipoic acid has a partially protective effect against this effects.

Keywords: Alpha Lipoic Acid, Kidney, Pregnancy, Rat, Tobacco Smoke.

\footnotetext{
区Elif Erdem Güzel

Mardin Artuklu Üniversitesi/Sağlık Bilimleri Fakültesi, Ebelik Bölümü, MARDiN.

e-posta: elfer192@hotmail.com

* Çalışma bütçesinin tamamı Fırat Üniversitesi Bilimsel Araştırma Projeleri Koordinasyon Birimi (FÜBAP)' nin TF. 16.06 proje no'lu kararı gereğince karşılanmıştır.
} 
GiRiş

$\mathrm{P}$

asif içicilik olarak da adlandırılan çevresel tütün dumanı (ÇTD) insan sağlığını olumsuz etkileyen durumların başında gelmektedir (1). Tütün dumanının 5.000'den fazla toksik kimyasal içerdiği ve bu içeriğin büyük bir kısmının kanserojen olduğu, diğer bir kısmının ise majör hastalıklara neden olduğu bilinmektedir (2). Ayrıca bu toksik bileşenlerin, üriner sistemini etkilediği, genel popülasyonda tip II diyabet görülme riskini arttırdığı tespit edilmiştir (3). Özellikle tütün dumanının majör komponenti olan nikotinin katekolamin, kortizol gibi dolaşımdaki insülin antagonist hormon seviyelerini arttırarak ve sempatik sinir sistemini etkileyerek insülin hassasiyetini bozduğu ortaya koyulmuştur (4). Gebelikte tütün dumanı maruziyetinin ise anne sağlığı üzerine birçok yan etkisi vardır (5). Tütün dumanı kaynaklı reaktif oksijen türleri (ROS), dokularda oksidan-antioksidan dengeyi bozarak oksidatif strese neden olur. Bu durum deoksiribonükleik asit (DNA) ve doku hasarına, ayrıca apoptozis yolu ile hücre ölümlerine yol açarak kanser gibi patolojik durumlarda önemli rol oynar (6).

Sigaranın böbrek damarlarında fonksiyonel bozukluğa yol açtığı ve bunun sonucu meydana gelen vasküler yataktaki endotelyal hasarların böbrek ile ilişkili hastalıklarda önemli rol oynadığı bilinmektedir $(7,8)$. Vasküler endotelyal büyüme faktörü (VEGF), fizyolojik ve patolojik durumlarda görev alan en güçlü endotelyal anjiyojenik büyüme faktörüdür. VEGF sinyali normal vasküler gelişim ve homeostazında gerekli olsa patolojik durumlarda damar büyümesini uyararak tümör gelişimine de katılır (9). Bu sinyal yolağının ROS üretimiyle uyardığı belirtilmiştir. Artan hücre içi ROS'un endotel, düz kas hücreleri ve makrofaj gibi birçok farklı hücre tipinde VEGF üretimini teşvik ettiği ortaya koyulmuştur $(10,11)$. Bu nedenle gebelik süresince bilinçli kullanılan antioksidanlar, artan serbest radikaller üzerine bir tedavi olanağı sağlayabilir ve bu yolla gerek annede gerekse çocukta görülebilecek patolojik durumları azaltabilir. Alfa lipoik asit (ALA), Ispanak, brokoli ve domates gibi bitkisel kaynaklarda yaygın olarak bulunan 1950 yılında ilk olarak sığır karaciğerinden, daha sonra patatesten izole edilen, kan-beyin bariyerini aşabilen, thioktik asit olarak da adlandırılan 8 karbonlu küçük bir moleküldür (12). Güçlü bir antioksidan olarak bilinen ALA'nın böbrek dokularında antioksidan koruma mekanizmalarında artış sağlayarak oksidatif stresi azalttığı rapor edilmiştir (13). Fakat ALA' nın gebelikte kullanımı üzerine yapılan çalışmalar oldukça sınırlıdır. Yapılan bir çalışmada diyabetli gebe farelere uygulanan ALA'nın yenidoğan farelerde gözlenen kardiyovasküler ve iskelet sistem malformasyonları ile nöral tüp defektlerinde anlamlı oranda azalmalara neden olduğu ortaya koyulmuştur (14).

$\mathrm{Bu}$ çalışmada gebelikte tütün dumanı maruziyetinin anne böbrek dokularında oluşturacağı olası hasara karşı ALA'nın etkilerinin araştırılması amaçlanmıştır.

\section{MATERYAL ve METOT}

Çalışma, Fırat Üniversitesi Hayvan Deneyleri Etik Kurulu'nun 2018/03 sayılı 26 no'lu kararı gereğince etik yönden uygun bulunarak yapıldı.

Çalışmada Fırat Üniversitesi Deneysel Araştırma Merkezi (FÜDAM)'nden temin edilen ortalama ağırlığı $160 \pm 10 \mathrm{gr}$ olan 28 adet 6 haftalık SpragueDawley cinsi dişi sıçanlar kullanıldı. Deney hayvanları FÜDAM hayvan laboratuvarında deney süresince sıçan pelet yemi ve musluk suyu ile 12 saat (07:0019:00) aydınlık -12 saat (19:00-07:00) karanlık periyodunda, $21 \pm 1{ }^{\circ} \mathrm{C}$ ortam sıcaklı̆ı̆ında beslendi. Dişi sıçanlar, erişkin erkek sıçanlar ile çiftleştirildi ve vajinal smearda spermin gözlendiği tarih embriyonik 0. gün olarak kabul edildi. Gebe kalan sıçanlar; Kontrol grubu, Tütün dumanı (TD) grubu, Tütün dumanı + Alfa lipoik asit (TD+ALA) grubu ve Alfa lipoik asit (ALA) grubu olmak üzere rastgele dört eşit gruba ayrıldı $(n=7)$. TD ve TD+ALA grubundaki sıçanlar, çiftleşmeden önce sekiz hafta ve gebelik süresince günde iki defa birer saat tütün dumanına maruz 
bırakıldı. TD+ALA ve ALA grubundaki sıçanlara ise çiftleşmeden önce sekiz hafta ve gebelik süresince 20 $\mathrm{mg} / \mathrm{kg}$ dozunda serum fizyolojikte çözdürülmüş ALA gün aşırı gavaj yolu ile uygulandı (15). On bir hafta boyunca süren uygulamalar doğum ile birlikte durduruldu. Tüm gruplardaki anne sıçanlar doğumdan sonra yirmi birinci gün olarak belirlenen laktasyon dönemi sonrası ketamin $(75 \mathrm{mg} / \mathrm{kg})$ ve xylazine $(10 \mathrm{mg} / \mathrm{kg})$ anestezisi altında dekapite edilerek, böbrek dokuları çıkarıldı.

\section{Deney Düzeneği ve Tütün Dumanının Verilmesi}

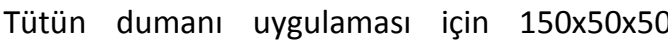
ebatlarında kapağı üstten açılabilir şekilde cam kafes yaptırıldı. Alt kısmına yakın yerde $1 \mathrm{~cm}$ genişliğinde delik açıldı. $10 \mathrm{~cm}$ çapında ve $12 \mathrm{~cm}$ yüksekliğinde teneke kutu alınarak içerisine $10 \mathrm{gr}$ tütün tartılarak konuldu. Daha sonra kafes içerisindeki sıçanlar ile tütünün içinde bulunduğu teneke kutu cam kafes içerisine bırakıldı. Yaklaşık $25 \mathrm{~cm}$ uzunluğunda plastik bir akvaryum pompa hortumunun bir ucu teneke kutuya takılırken diğer ucu ise hava pompasına (AP001 Xilong Aquarium Air Pump, China) takıldı. Tütün yakıldı ve alevlenebilmesi için hava pompasından hava verildi. Tütünden duman çıkmasıyla beraber cam kafesin kapağı kapatıldı ve dumanın kafesin her tarafına yayılması sağlandı. Bir saatin sonunda cam kafesin kapağı açıldı ve sıçanlar kafesleriyle birlikte dışarı alındı. Deney süresi olan on bir hafta boyunca bu işlemler her gün 9:00-10:00 ve 14:00-15:00 saatleri arası günde iki kere tekrarlandı.

\section{Histolojik Takip ve Boyama}

Histopatolojik değerlendirmeler için 24 saat süre ile $\% 10$ 'luk formaldehit içerisinde fikse edilen böbrek dokuları çeşme suyu altında yıkandı. Yıkanan dokular rutin histolojik takip serilerinden geçirilerek parafin bloklara gömüldü. Elde edilen parafin bloklardan $5 \mu \mathrm{m}$ kalınlığında kesitler alındı. Hazırlanan preparatlar Hematoksilen-Eozin (H\&E) ve Periyodik Asit-Schiff (PAS) boyamaları ile boyanarak ışık mikroskobu altında (Novel N-800M x20) incelendi ve fotoğraflandı. Değişiklikler histopatolojik durumlarına göre yok (0), hafif (1), orta (2) ve şiddetli (3) olarak değerlendirilerek histoskor tablosu çıkarıldı.

\section{İmmunohistokimyasal Boyama}

Böbrek dokusunda VEGF immünreaktivitesinin belirlenmesi için, soğutulmuş parafin bloklardan polilizinli lamlara $5 \mu \mathrm{m}$ kalınlığında kesitler alındı. Deparafinizasyon ve şeffaflaştırma işleminden sonra dokular azalan dereceli alkol serilerinden geçirilip antigen retrieval için sitrat tampon solüsyonunda $\mathrm{pH}$ : 6'da mikrodalga fırında (750W) 12 dakika kaynatıldı. Endojen peroksidaz aktivitesini önlemek için hidrojen peroksit bloker (TA-125-HP Lot No: HP18180, Hydrogen Peroxide Block, Thermo Scientific) ile muamele edildi. Zemin boyasını engellemek için 5 dakika Ultra V Block (TA-125-UB, Ultra V Block, Thermo Scientific) uygulamasından sonra primer antikor (RB-9031-P lot No: 9031P1505A, Polyclonal Anti-VEGF Antibody) damlatılan dokular 60 dakika oda ısısında karanlık ve nemli ortamda inkübe edildi. İnkübasyondan sonra dokular sekonder antikor (TP060-BN, Biotinylated Goat Anti-Poliyvalent (antimouse / rabbit (gG), Thermo Scientific) ile muamele edildi. Hazırlanan preparatlar ışık mikroskobunda (Novel N-800M) incelenerek değerlendirildi ve fotoğraflandı. İmmünohistokimyasal boyanmanın değerlendirilmesinde; immünreaktivitenin yaygınlığı (0.1: <\%25, 0.4: \%26-50, 0.6: \%51-75, 0.9: \%76-100) ve şiddeti (0: yok, +0.5: çok az, +1: az, +2: orta, +3: şiddetli) esas alınarak histoskor tablosu oluşturuldu.

\section{Malondialdehit (MDA) Düzeyinin İncelenmesi}

Dekapitasyondan sonra çıkarılan böbrek dokuları serum fizyolojik ile yıkanıp $-20^{\circ} \mathrm{C}^{\prime}$ de çalışma gününe kadar saklandı. Çözdürülen doku örnekleri \%1.15'lik KCl ile 1:100 oranında (ağırlık/hacim) sulandırılıp homojenizatör (Ultra-Turax T25, IKALabortecknik) yardımıyla doku tamamen parçalandı. Homejenat 3500 rpm'de 15 dakika santrifüj edildi. Elde edilen süpernatantlarda malondialdehit (MDA) tayini Placer metoduna göre yapıldı (16). Bu metodun temeli lipit peroksidasyonu sonucu oluşan aldehit 
ürünlerinden biri olan MDA ile tiobarbitürik asit (TBA)'in reaksiyonuna dayanmaktadır. Reaksiyon sonucunda pembe renkli bir kompleks oluşmakta ve çözeltinin absorbansı 532 nm'de spektrofotometre (Shimadzu AA-680) cihazıyla ölçülerek, lipit peroksidasyonunun derecesi belirlenmektedir.

\section{İstatistiksel Analiz}

Tüm istatistiksel analizler SPSS 22.0 (Statistical Package for Social Sciences) paket programında yapıldı. Veriler ortalama \pm standart sapma değerleri olarak sunuldu. $\mathrm{P}<0.05$ değeri anlamlı olarak kabul edildi.

Normal dağılım gösteren çoklu grupların aralarındaki farklılıkları test etmek için Tek Yönlü Varyans Analizi (ANOVA) uygulandı. ikili karşılaştırmalar için ise Post-hoc Tukey testi kullanıldı.

\section{BULGULAR}

\section{Histopatolojik Bulgular}

Işık mikroskobu incelemelerinde kontrol grubuna ait böbrek dokularında, glomerül ve tübül yapıları normal olarak izlendi (Şekil 1a,3a). TD grubuna ait böbrek dokularında kortekste, glomerüllerde mezangial hücre ve matriks artışı, Bowman boşluğunda genişleme, glomerül ve tübül bazal membranlarında kalınlaşma belirgin olarak görüldü. Ayrıca renal tübül epitellerinde deskuamasyon ve dejenerasyon, tübül epitellerindeki piknotik çekirdekli nekrotik hücreler, tübüllerde hiyalin birikimi, tübüler dilatasyon, peritübüler vasküler konjesyon, perivasküler ödem, proksimal tübüllere ait fırçamsı kenarda bozulmalar ve ayrılmalar, intertisyumda orta derecede mononükleer hücre infiltrasyonu ve duvar bütünlüğü bozulmuş olan dejenere Henle kulpu bulguları izlendi (Şekil 1b,2a,2b,2c,2d,3b). TD+ALA grubuna ait böbrek kesitlerinde ise histopatalojik bulguların devam ettiği fakat TD grubuna göre şiddetinin istatistiksel olarak azaldığı izlendi $(P<0.05)$ (Şekil 1c,3c). ALA grubuna ait böbrek kesitlerinde ise yer yer konjesyon alanları dışında glomerül ve tübüler yapıların kontrole yakın olduğu gözlendi ( $P>0.05$ ) (Şekil 1d,3d) (Tablo1).

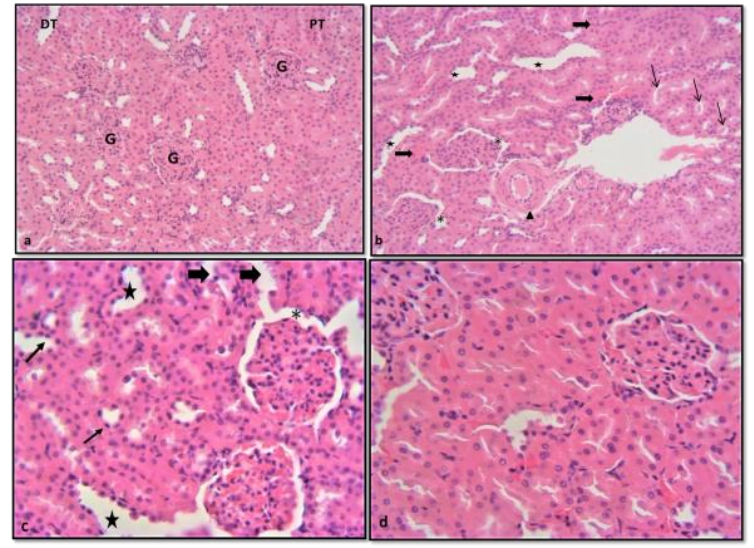

Şekil 1: a; Kontrol grubuna ait glomerül (G) ve tübüler yapılar normal olarak ayırt edilmekte. DT: distal tübül, PT: proksimal tübül. Hematoksilen \& Eozin, 200x b; TD grubuna ait tübüler dilatasyon (yıldız), tübüllerde hiyalin birikimi (ince ok), peritübüler vasküler konjesyon (kalın ok), Bowman boşluğunda genişleme $\left({ }^{*}\right)$, perivasküler ödem (A). Hematoksilen \& Eozin, 200x c; TD+ALA grubuna ait glomerüler ve tübüler yapılardaki histopatalojik bulguların TD grubuna kıyas ile şiddetli olmadığı gözlenmektedir. Tübül epitellerindeki piknotik çekirdekli nekrotik hücreler (ince ok), renal tübüllerde dilatasyon (yıldız), Bowman boşluğunda genişleme $\left({ }^{*}\right)$, renal tübül epitellerinde dejenerasyon (ok başı). Hematoksilen \& Eozin, 400x d; ALA grubuna ait yer yer konjesyon alanları dışında glomerül ve tübüler yapıların kontrole yakın olduğu ayırt edilmekte. Hematoksilen \& Eozin, 400x.

Figure 1: a; Glomerular (G) and tubular structures of the control group are normally distinguished. DT: distal tubule, PT: proximal tubule. Hematoxylin \& Eosin, 200x b; tubular dilatation (star), hyaline accumulation in the tubules (thin arrow), peritubular vascular congestion (thick arrow), enlargement of Bowman's space $\left({ }^{*}\right)$, perivascular edema ((A) belonging to the TS group. Hematoxylin \& Eosin, 200x c; The histopathological findings in the glomerular and tubular structures of the TS+ALA group are not severe compared to the TS group. Necrosis of the renal epithelium with pyknotic nucleate (thin arrow), dilatation in the renal tubules (star), enlargement of Bowman's space ${ }^{*}$ ), degeneration in the renal tubule epithelium (arrowhead) belonging to the TS+ALA group. Hematoxylin \& Eosin, 400x d; it is distinguished that the glomeruli and tubular structures are close to the control except some places of congestion of the ALA group. Hematoxylin \& Eosin, 400x. 


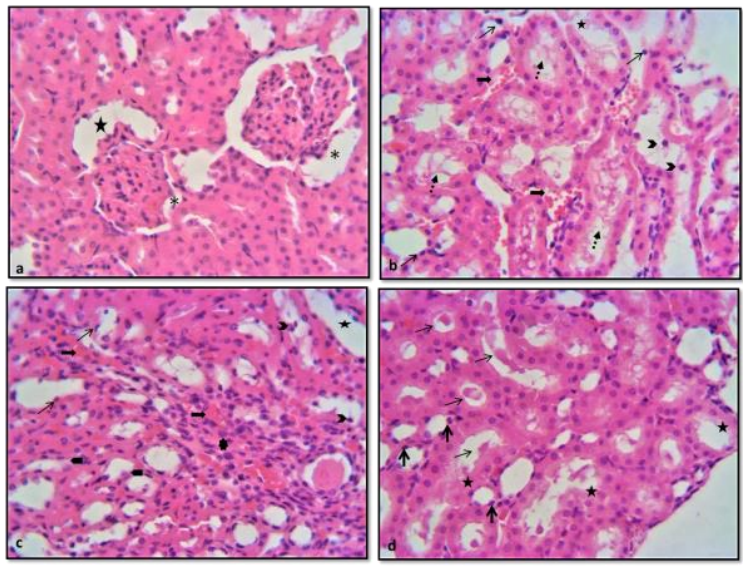

Şekil 2: a; TD grubuna ait tübüler dilatasyon (yıldız), Bowman boşluğunda genişlemeler ( $\left.{ }^{*}\right)$, b; TD grubuna ait renal tübül epitellerinde deskuamasyon $(\boldsymbol{\Sigma})$ ve dejenerasyon (yıldız), tübül epitellerindeki piknotik çekirdekli nekrotik hücreler (ince ok), peritübüler vasküler konjesyon (kalın ok), proksimal tübül epitellerine ait fırçamsı kenarlarında bozulma ve

ayrılmalar (* ) c; TD grubuna ait renal tübül epitellerinde deskuamasyon $(\boldsymbol{\nabla})$, tübüler dilatasyon (yıldız), tübül epitellerindeki piknotik çekirdekli nekrotik hücreler (ince ok), peritübüler vasküler konjesyon (kalın ok), intertisyumda orta derecede mononükleer hücre infiltrasyonu (\$), duvar bütünlüğü bozulmuş olan dejenere Henle kulpu (a) d; TD grubuna ait renal tübül epitellerinde dejenerasyon (yıldız), tübül epitellerindeki piknotik çekirdekli nekrotik hücreler (kalın ok), tübüllerde hiyalin birikimi (ince ok). Hematoksilen \& Eozin, 400x. Figure 2: a; tubular dilatation (star), enlargement of Bowman's space $(*)$ belonging to the TS group b; desquamation ( $\boldsymbol{\Sigma})$ and degeneration (star) in the renal tubular epithelium, pyknotic nucleated necrotic cells in the tubule epithelium (thin arrow), peritubular vascular congestion (thick arrow), deterioration and separation on the brush border of proximal tubule epithelium $\left({ }^{*}\right)$ belonging to the TS group c; desquamation in the renal tubular epithelium ( $\boldsymbol{\Sigma})$, tubular dilatation (star), peritubular vascular congestion (thick arrow), moderate mononuclear cell infiltration in the interstitium ( degenerated Henle handle with deteriorated wall integrity (a) belonging to the TS group d; Degeneration in the renal tubule epithelium (star), necrosis of the renal epithelium with pyknotic nucleate (thick arrow), accumulation of hyaline in the tubules (thin arrow) belonging to the TS group. Hematoxylin \& Eosin, 400x.

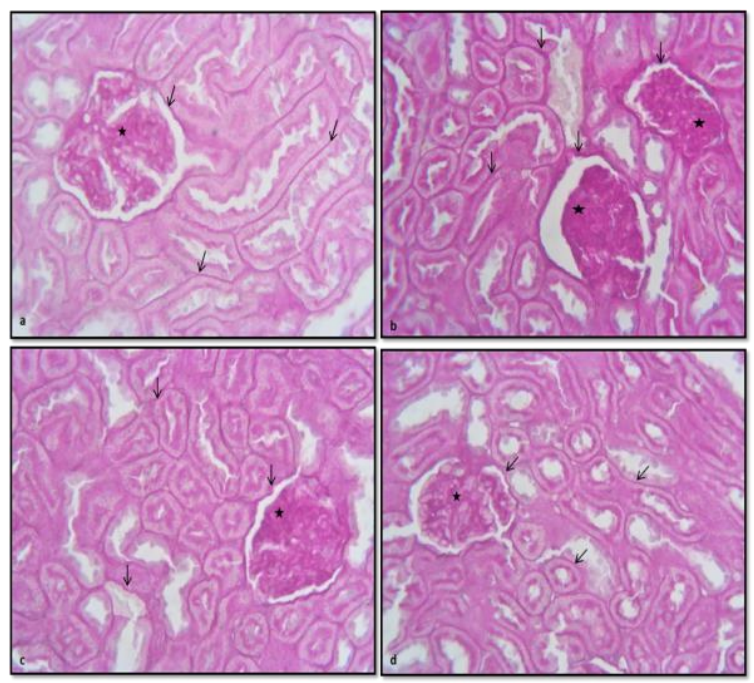

Şekil 3: a; Kontrol grubuna ait glomerül ve tübül bazal membranları (ok) ve glomerüler mezangial matriks (yıldız) b; TD grubuna ait glomerül ve tübül bazal membranlarında kalınlaşma (ok) veglomerüllerde mezangial matriks artışı (yıldız) c; TD+ALA grubuna ait glomerül ve tübül bazal membranlarında kalınlaşma (ok) ile mezangial matriks artışının (yıldız) devam ettiği, fakat TD grubuna kıyas ile bu artışın azaldığı gözlenmekte d; ALA grubuna ait glomerül ve tübül bazal membranları (ok) ile glomerüler mezangial matriks (yıldız) kontrol grubuna yakın gözlenmektedir. PAS, 400x.

Figure 3: a; Glomerular and tubule basement membranes (arrow) and glomerular mesangial matrix (star) belonging to the control group b; Increase thickness of glomerular and tubular basement membranes (arrow) and increase glomerular mezangial matrix (star) belonging to the TS group c; It is observed that thickening glomeruli and tubule basement membranes (arrow) and glomerular mesangial matrix increase (star) are continued in the TS+ALA group, but this increase is decreased compared to the TS group $d$; The glomerulus and tubule basal membrane (arrow) and the glomerular mesangial matrix (star) belonging to the ALA group are observed close the control group. PAS,400x. 
Tablo 1: Böbrek dokusundaki histolojik değerlendirmelere ait histoskor tablosu.

Table 1: Histoskore table of histological evaluations belonging to the renal tissue.

\begin{tabular}{lcccc}
\hline & Kontrol & TD & TD+ALA & ALA \\
\hline Glomerül mezengial matriks artışı & $0.00 \pm 0.00$ & $2.16 \pm 0.16^{\mathrm{a}}$ & $1.50 \pm 0.22^{\mathrm{ab}}$ & $0.16 \pm 0.16$ \\
Bowman boşluğunda genişleme & $0.00 \pm 0.00$ & $2.00 \pm 0.1^{\mathrm{a}}$ & $1.00 \pm 0.00^{\mathrm{ab}}$ & $0.28 \pm 0.48^{\mathrm{b}}$ \\
$\begin{array}{l}\text { Glomerül ve tübül bazal membranlarında } \\
\text { kalınlaşma }\end{array}$ & $0.00 \pm 0.00$ & $2.16 \pm 0.3^{\mathrm{a}}$ & $1.5 \pm 0.22^{\mathrm{a}}$ & $0.00 \pm 0.00^{\mathrm{b}}$ \\
Renal tübül epitellerinde deskuamasyon ve & $0.00 \pm 0.00$ & $2.14 \pm 0.69^{\mathrm{a}}$ & $1.28 \pm 0.48^{\mathrm{ab}}$ & $0.00 \pm 0.00^{\mathrm{b}}$ \\
dejenerasyon & $0.00 \pm 0.00$ & $2.14 \pm 0.37^{\mathrm{a}}$ & $0.5 \pm 0.22^{\mathrm{ab}}$ & $0.00 \pm 0.00^{\mathrm{b}}$ \\
Tübüllerde hiyalin birikimi & $0.00 \pm 0.00$ & $2.00 \pm 0.00^{\mathrm{a}}$ & $1.00 \pm 0.37^{\mathrm{ab}}$ & $0.16 \pm 0.16^{\mathrm{b}}$ \\
Tübüler dilatasyon & $0.00 \pm 0.00$ & $1.83 \pm 0.16^{\mathrm{a}}$ & $0.5 \pm 0.22^{\mathrm{b}}$ & $0.33 \pm 0.31^{\mathrm{b}}$ \\
Peritübüler vasküler konjesyon & $0.00 \pm 0.00$ & $1.5 \pm 0.53^{\mathrm{a}}$ & $0.66 \pm 0.21^{\mathrm{b}}$ & $0.00 \pm 0.00^{\mathrm{b}}$ \\
Perivasküler ödem & $0.00 \pm 0.00$ & $2.66 \pm 0.21^{\mathrm{a}}$ & $1.5 \pm 0.22^{\mathrm{ab}}$ & $0.00 \pm 0.0^{\mathrm{b}}$ \\
Piknotik çekirdekli hücre & $0.00 \pm 0.00$ & $2.33 \pm 0.2^{\mathrm{a}}$ & $1.16 \pm 0.3^{\mathrm{ab}}$ & $0.00 \pm 0.0^{\mathrm{b}}$ \\
Fırçamsı kenarda bozulma/ ayrılma & $0.00 \pm 0.0$ & $2.00 \pm 0.25^{\mathrm{a}}$ & $1.00 \pm 0.36^{\mathrm{ab}}$ & $0.33 \pm 0.21^{\mathrm{b}}$ \\
Mononükleer hücre infiltrasyonu & $0.00 \pm 0.0$ & $2.16 \pm 0.04^{\mathrm{a}}$ & $1.16 \pm 0.12^{\mathrm{ab}}$ & $0.00 \pm 0.0$ \\
Dejenere Henle kulpu & & &
\end{tabular}

\section{İmmünohistokimyasal Değerlendirmeler}

VEGF immünreaktivitesi için yapılan immünohistokimyasal boyamanın ışık mikroskobu altında incelenmesi sonucu; kontrol grubuna ait VEGF immünreaktivitesi böbrek tübüllerinde ve glomerül podosit hücrelerinde gözlendi (Şekil 4a). TD grubunda, kontrol grubu ile karşılaştırıldığında anlamlı bir artış vardı $(\mathrm{P}<0.05)$ (Şekil 4b). TD+ALA grubunda ise, TD grubu ile kıyaslandığında istatistiksel olarak anlamlı bir azalma gözlendi $(P<0.05) \quad$ (Şekil 4c). ALA grubuna ait VEGF immünreaktivitenin kontrol grubuna yakın olduğu gözlendi ( $P>0.05$ ) (Şekil 4d) (Tablo 2).

Tablo 2: Böbrek dokusundaki VEGF immünreaktivitesi.

Table 2: VEGF immunoreactivity in kidney tissue.

\begin{tabular}{ll}
\hline GRUPLAR & $\begin{array}{l}\text { HiSTOSKOR } \\
\text { (yaygınlık } x \text { şiddet) }\end{array}$ \\
\hline Kontrol grubu & $1.13 \pm 0.22$ \\
TD grubu & $2.40 \pm 0.18^{\mathrm{a}}$ \\
TD+ ALA grubu & $2.00 \pm 0.24^{\mathrm{ab}}$ \\
ALA grubu & $1.23 \pm 0.20^{\mathrm{b}}$ \\
\hline
\end{tabular}

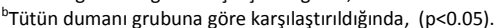

Değerler ortalama tstandart sapma olarak verilmiştir.

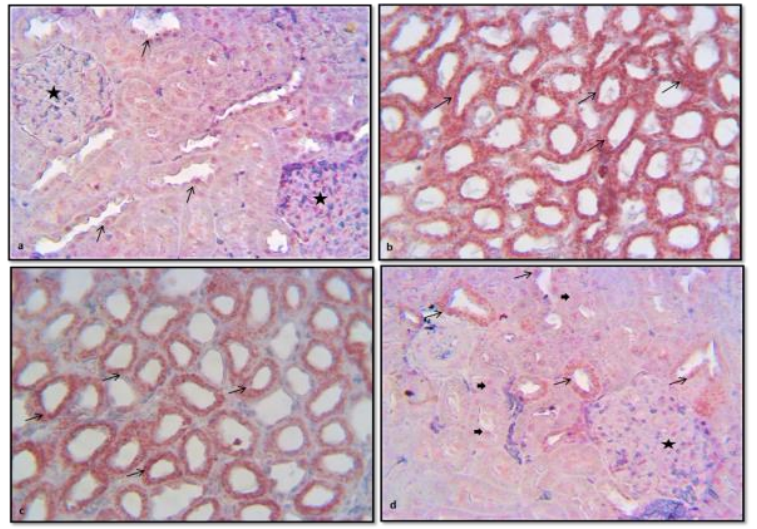

Şekil 4: a; Kontrol grubuna ait böbrek tübüllerinde (ok) ve glomerül podositlerinde (yıldız) VEGF immünreaktivitesi b; TD grubuna ait böbrek tübüllerinde (ok) artan VEGF immünreaktivitesi c; TD+ALA grubuna ait böbrek tübüllerinde (ok) VEGF immünreaktivitesi d; Kontrol grubuna ait böbrek distal tübüllerinde (ince ok), proksimal tübüllerinde (kalın ok) ve glomerül podositlerinde (yıldız) VEGF immünreaktivitesi (x400).

Figure 4: a; VEGF immunoreactivity in the kidney tubules (arrow) and glomerular podocytes (star) belonging to the control group $b$; Increased VEGF immunoreactivity in the renal tubules belonging to the TS group (arrow) c; VEGF immunoreactivity in the renal tubules belonging to the TS+ALA group (arrow) d; VEGF immunoreactivity in the distal tubules of the kidney (thin arrow), proximal tubules (thick arrow) and glomerular podocytes (star) belonging to the control group (x400). 
MDA Düzeyleri

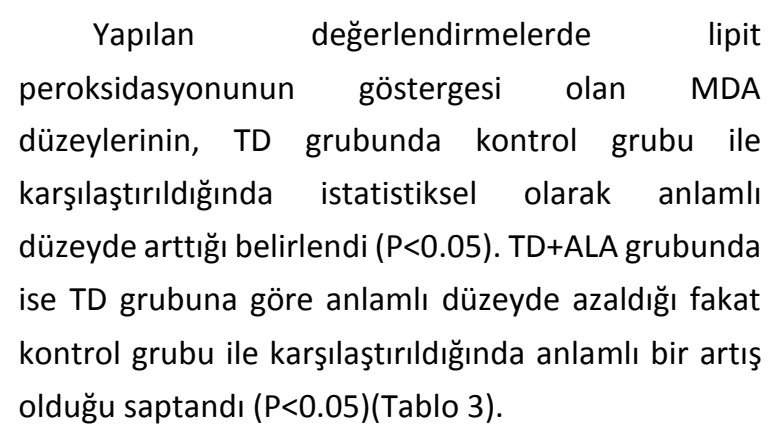

Tablo 3: Böbrek dokusundaki MDA düzeyleri.

Table 3: MDA levels in kidney tissue.

\begin{tabular}{ll}
\hline GRUPLAR & $\begin{array}{l}\text { MDA } \\
\text { (nmol/g doku) }\end{array}$ \\
\hline Kontrol grubu & $51.531 \pm 2.30$ \\
TD grubu & $87.722 \pm 1.13 \mathrm{a}$ \\
TD+ALA grubu & $68.716 \pm 1.47 \mathrm{ab}$ \\
ALA grubu & $53.500 \pm 1.85 \mathrm{~b}$ \\
\hline
\end{tabular}

Değerler ortalama \pm standart sapma olarak verilmiştir.

${ }^{a}$ Kontrol grubuna göre karşılaştıııldığında,

${ }^{b}$ Tütün dumanı grubuna göre karşıllaştıııılı̆ı̆ında, $(p<0.05)$.

\section{TARTIŞMA ve SONUÇ}

Son yıllarda, sigaranın kronik böbrek hastalıkları ile olan ilişkisi üzerine çalışmalar oldukça fazladır $(3,8,17)$. Sigara dumanı maruziyetinin diyabetik nefropati, iskemik nefropati, nefrolosklorozis, IgA nefropati gibi böbrek hastalıklarının gelişmesine ve ilerlemesine neden olduğu bildirilmiştir $(17,18)$. Ayrıca sigaranın insülin direncine yol açarak metabolik sendrom ve tip2 diyabet riskini arttırdığı tespit edilmiştir (19). Bu hastalıkların patomekanizması oldukça komplekstir ve sigara ile ilişkileri hala net olarak anlaşılamamıştır. Gebelik boyunca sigara veya tütün ürünleri maruziyetinin anne sağlığına kısa ve uzun vadede olumsuz etkilere yol açtığı birçok farklı çalışma ile kanıtlanmıştır $(5,20)$. $\mathrm{Bu}$ nedenle gebelikte tütün dumanı maruziyetinin annenin böbrekleri üzerinde hasar oluşturabileceği ve bu hasarın gebelikte gözlenen ve patofizyolojisinde oksidatif stres ile endotelyal disfonkisyonun rol oynadığı böbrek hastalıkları açısından risk oluşturabileceği kanaatindeyiz.
Pasif sigara dumanındaki toksik maddelerden biri olan nikotinin nefrotoksik etkisi olduğu ve nefropatiyi uyardığı bilinmektedir (21). Sigara indüklü renal hasarın akut etkisi özellikle sempatik sinir aktivitasyonunun artması, kronik etkisi ise endotelyal hücre disfonksiyonu üzerinden açıklanmıştır. Tübüler fonksiyon bozukluğu, artan intraglomerüler kapiler basınç, insülin direnci, artan sempatik sinir aktivitesi, oksidatif stres, matriks birikimi, endotel ve mezengial hücre proliferasyonu sigara ile uyarılan renal hasarlarda rol alan patomekanizmalardan bazılarıdır (22). Sigara ile uyarılan böbrek hasarlarının patomekanizması bu çoklu nedenlere bağı olabilir fakat majör sebebinin oksidatif stres olduğu düşünülmektedir (23). Sigara dumanı reaktif oksijen ve nitrojen türlerinin üretimini uyararak hücrelerde oksidatif stres üretimine, inflamatuar gen ekspresyonlarının artışına ve endotelyal disfonksiyonuna yol açar (24). Artan ROS'un, mezengial hücrelerdeki ekstrasellüler matriks üretiminde ve proksimal tübül ile kapiller endotel hücrelerdeki geçirgenlik artışına neden olarak enerji üretimi ve hücresel transport için gerekli olan kapasiteyi ve yapısal bütünlüğü bozduğu ve bu yolla böbrek hasarlarının ilerlemesine yol açtığı ortaya koyulmuştur $(16,25)$. Şahin ve ark. (26) yaptıkları çalışmada stres ile uyarılmış artan oksidatif stresin nefron tübüllerinde ve glomerüllerde nekrotik değişikliklere ve ciddi hücresel hasarlanmalara neden olduğunu ve bu hasarın, strese bağlı olarak tetiklenen lipit peroksidasyondaki artıştan kaynaklanmış olabileceğini rapor etmişlerdir. Sıçanlar üzerinde yapılan çalışmalarda tütün bitkisinin renal korteks glomerüllerinde daralmaya, hemorajiye ve tübüler dejenerasyona yol açtığı bildirilmiştir (27). Diyabetli ve diyabetli olmayan sigara içen hastalarda proksimal tübül hücre disfonksiyonu ve tübüler hücre hasarı gözlenmiştir ki bu bulgular tübülointerstisyel hücre hasarı ve kronik böbrek hastalığının gelişimi ile ilişkilendirilmiştir (28). Ayrıca oksidan kaynağı olan tütün dumanının hücre membranlarında hasar oluşturarak, membran geçirgenliğini arttırdığı ve sonunda hücrelerde ölüme yol açtığı bilinmektedir 
(29). Bizim çalışmamızda tütün dumanı grubuna ait böbrek kesitlerinde oksidanların yol açtığı tübüler epitel hücrelerinde deskuamasyon ve dejenerasyon, piknotik çekirdekli nekrotik epitel hücrelerine ve perivasküler ödem alanlarına rastlanıldı. Ayrıca diğer çalışmalarla uyumlu olarak glomerüllerde mezengial matriks artışı, Bowman boşluğunda genişleme, bazal membran kalınlaşması, tübüllerde hiyalin birikmesi ve inflamasyon alanları gözlendi. Bu karakteristik değişikliklerin metabolizma atık ürünlerinin tutulmasına neden olabileceği ve böylesi anormalliklerin devam etmesi halinde böbrekteki duyarlı homeostatik mekanizmaların kaybına neden olabileceği bildirilmiştir (30). Ayrıca glomerüler mezengial hücreler herhangi bir inflamatuar uyar sonucu uyarıldıklarında serbest radikaller, sitokin, büyüme faktörü, eikosanoidler, nitrik oksit ve endotelin gibi birçok inflamatuar mediatörün oluşumuna yol açarak glomerülde inflamatuar cevabı başlatabilir. Ekstrasellüler matriks üretimine de katılarak mezengial hücrelerin aşırı artışına ve dolayısıyla glomerüloskleroza götüren bir tabloya yol açabilir. Bu nedenle tütün dumanı grubuna ait böbrek kesitlerindeki artan mezengial hücreler glomerüler patolojinin bir göstergesi olabilir. Bulgulardan bir diğeri olan Bowman boşluğundaki genişleme ise glomerüllerde hasarlanmayı gösterebilen erken bir bulgu olarak değerlendirilebilir. Ancak glomerül yapısındaki yapısal bozukluğun daha net ortaya koyulabilmesi için ultrastrüktürel bir incelemenin yapılması gereklidir. Bizim çalışmamızda histolojik değerlendirmeler sadece ışık mikroskobu altında yapılabildi. Ancak bulgularımız; MDA düzeyleri ile birlikte değerlendirildiğinde başlıca patolojinin, ROS artışına bağı olarak ortaya çıkan glomerüler hasar kaynaklı olduğunu düşündürmektedir.

VEGF-A olarak da adlandırılan VEGF, 34-46 kDa büyüklüğünde, embriyogenezde kan damarları oluşumunda görev alan ve bu özelliği ile dokularda anjiogenezisi başlatan birçok farklı hücre tipinde üretilen bir proteindir (31). Insan ve kemiricilerin böbrek dokularında, glomerüler podositlerde, distal ve proksimal toplayıcı tübüllerde ve toplayıcı kanallarda VEGF üretimi gerçekleşir $(32,33)$. VEGF'in potansiyel anjiogenezisi uyarması nedeniyle renal hücre karsinomlarını teşvik ettiği bildirilmiştir (34). Sigara, vasküler hastalıklar ve çeşitli kanser türleri için önemli bir risk faktörüdür ve böbrekler, sigaranın yol açtığı hasarlar için önemli bir hedef organıdır $(21,22,24)$. Birçok çalışmada ROS ile anjiogenezis arasında pozitif ilişki olduğu gösterilmiştir. Sigara dumanındaki hidrojen peroksit, nikotin ve majör metaboliti olan kotinin gibi toksik komponentlerin endotel ve vasküler düz kas hücrelerinden VEGF üretimini uyardığı, böylece anjiojenik yanıtları düzenlediği ortaya koyulmuştur $(35,36)$. Bunun yanı sıra VEGF'nin endotel hücrelerindeki nikotinamid adenin dinükleotit fosfat (NADPH) oksidaz aktivasyonu yolu ile ROS üretimini daha da arttırdığı bildirilmiştir (37). VEGF ekspresyonundaki bu artış ise tümör gelişimindeki neovaskülarizasyon ile ilişkilendirilmiştir. Ayrıca dokudaki artan VEGF seviyelerinin kapiler sızıntılara neden olarak ödeme yol açtığı da ortaya koyulmuştur (38). Bununla ilgili yapılan bir çalışmada Tip1 diyabetli hastaların serum VEGF düzeyleri ile kapiler geçirgenlik arasında pozitif ilişki olduğu gösterilmiştir (39). VEGF inhibisyonunun diyabetle ilişkili glomerüler hiperfiltrasyonu, glomerüler hipertrofi ve idrar albümin boşaltımını metabolik kontrolü etkilemeden ortadan kaldırdığı ortaya koyulmuştur (40). VEGF, normal böbreklerde glomerüler geçirgenliği düzenlerken, patolojik durumlarda proteinüriyi uyarmaktadır. Örneğin fareler üzerinde yapılan bir çalışmada podosite spesifik VEGF-164'ün aşırı ekspresyonunun glomerüler lezyona yol açarak proteinüri, glomerulomegali, mesangial ve bazal membran kalınlaşması gibi mürin diyabetik nefropatide görülen benzer yapısal ve fonksiyonel değişikliklere yol açtığı gözlenmiştir (41). Ayrıca, hipoksi veya herhangi bir hasarda tübüler hücrelerin VEGF üretimine yanıt vererek, tübüler hasarın üstesinden gelmek için, peritübüler kapiler proliferasyonunu uyardığı ortaya koyulmuştur (42). Çalışmada hipoksik ortam ile ilgili bir değerlendirme yapılmamıştır fakat tütün 
dumanının dokulardaki oksijenizasyonu azalttığı ve damarlarda daralmaya yol açarak dokuların beslenmesini önlediği bilinmektedir (43). Bu bilgilerden yola çıkarak VEGF artışının bir nedeninin de bu tütün dumanı kaynaklı hipoksik ortamın olabileceği düşünülmektedir.

Oksidatif stres faktörü olan sigaranın antioksidan kapasiteyi azaltarak, insanlarda ve deneysel hayvan modellerinde çeşitli hastalıklara yol açtığı bildirilmiştir $(21,24)$. Tütün dumanına bağı olarak artan ROS'un, hücrelerde hasara yol açan membran peroksidasyonuna ve MDA oluşumuna neden olduğu bilinmektedir. MDA, dokulardaki lipit peroksidasyonunu belirleyen bir belirteçtir. Sigara dumanındaki reaktif peroksil radikalleri ve asetaldehit içeriğinin lipit peroksidasyonu arttırdığı bilinmektedir. $\mathrm{Bu}$ nedenle sigara içenlerde peroksidasyon ürünü olan plazma ve doku MDA düzeyleri yüksek beklenmektedir (44). Çalışmada tütün dumanı grubuna ait böbrek dokularında MDA değerlerinin kontrol grubuna göre anlamlı ölçüde arttığı tespit edildi. Bu da tütün dumanının böbrek dokusunda yol açtığı hasarların ROS kaynaklı olduğunu düşündürmektedir.

Oksidatif stres, organizmada zararlı serbest radikallerin oluşmasıyla ortaya çıkar. Serbest radikaller, normal bir metabolizmanın devamı ve hücrede enerji üretimi için gerekli olan birçok reaksiyon tarafından üretilebilmektedir. Toksik düzeydeki serbest radikaller lipitler, proteinler ve nükleik asitlerle etkileşerek membran bütünlüğünün kaybına, proteinlerde yapısal ve fonksiyonel değişikliklere ve genetik mutasyonlara sebebiyet vermektedir. Organizma bu zararlı radikallerin etkisiyle başa çıkabilmek için bazı enzimatik ve enzimatik olmayan antioksidan savunma sistemlerine sahiptir (45). Enzimatik olmayan antioksidanlardan biri olan ALA, mitokondrilerin pürüvat dehidrogenaz ve alfa ketogluterat dehidrogenaz enzimlerinin kofaktörü olarak görev alan güçlü bir antioksidandır. Sıçanlar üzerinde yapılan bir çalışmada, metotreksat ile böbreklerde oluşturulan oksidatif hasara karşı ALA'nın, anti- inflamatuar ve anti-oksidan etkileri sayesinde, kısmen koruma sağladığı ortaya koyulmuştur (46). Çalışmamızda da ALA 'nın antioksidatif etkisi ile tütün dumanı ile meydana gelen böbrek dokularındaki artan MDA düzeylerini ve histopatalojik bulguları azalttığı gözlendi.

$\mathrm{Bu}$ çalışmanın bulguları, önemli bir sosyal ve sağlık problemi oluşturan çevresel tütün maruziyetinin ve pasif içiciliğin özellikle gebelik boyunca annenin teneffüs etmesini önlemek ve bu kişileri korumak için önlemlerin alınmasının önemini tekrar vurgulamaktadır. Bu nedenle gebelik süresince kadınların sigara veya tütün ürünlerine olan maruziyetin önlenebilmesi annenin sağlığı açısından oldukça önem arz etmektedir.

Sonuç olarak gebelikte tütün dumanı kaynaklı oksidatif hasarın anneye ait böbrek dokularında hasara yol açtığı, güçlü bir antioksidan olan ALA uygulamasının ise bu hasarı kısmen engellediği gözlendi. Oksidatif strese bağı olarak artan lipit peroksidasyonu ile meydana gelen glomeruler ve tübüler hasarların, kanın filtrasyonunda ve reabsorbsiyon mekanizmalarında, renal histopatolojisinde ve fizyolojisinde önemli bozulmalar meydana getirebileceğini, fakat bu etkinin mekanizmalarını açıklayabilecek daha ileri düzeyde biyokimyasal ve ultrastrüktürel çalışmalara ihtiyaç olduğunu düşünmekteyiz.

\section{KAYNAKLAR}

1. Vanker A., Gie RP., Zar HJ., 2017. The association between environmental tobacco smoke exposure and childhood respiratory disease: a review. Expert Rev Respir Med, 11, 661-673.

2. Thielen A., Klus H., Muller L., 2008. Tobacco smoke: unraveling a controversial subject. Exp Toxicol Pathol, 60, 141-156.

3. Keith RJ., Rifai M., Defilippis AP., 2016. Tobacco use, insulin resistance, and risk of type 2 diabetes: results from the multi-ethnic study of atherosclerosis. PLos ONE, 11, 1-24.

4. Lucini D., Bertocchi F., Malliani A., Pagani M., 1996. A controlled study of the autonomic 
changes produced by habitual cigarette smoking in healthy subjects. Cardiovascular Res, 31, 633639.

5. Karcaaltincaba D., Kandemir Ö., Yalvac S., Güvendağ Güven ES., Yildirim BA., Haberal A., 2009. Cigarette smoking and pregnancy: results of a survey at a turkish women's hospital in 1,020 patients. J Obstet Gynaecol, 29, 480-486.

6. Niemann B., Rohrbach S., Miller MR., Newby DE., Fuster V., Kovacic JC., 2017. Oxidative stress and cardiovascular risk: obesity, diabetes, smoking, and pollution: Part 3 of a 3-part series. J Am Coll Cardiol, 70, 230-251.

7. Blann AD., McCollum CN., 1993. Adverse influence of cigarette smoking on the endothelium. Thromb Haemost, 7, 707-711.

8. Boor P., Casper S., Celec P., 2009. Renal, vascular and cardiac fibrosis in rats exposed to passive smoking and industrial dust fibre amosite. J Cell Mol Med, 13, 4484-4491.

9. Shibuya M., 2008. Vascular endothelial growth factordependent and-independent regulation of angiogenesis. BMB Rep, 41, 278-286.

10. Wang Y., Zang QS., Liu Z., Wu Q., Maass D., Dulan G., Shaul PW., Melito L., Frantz DE., Kilgore JA., Williams NS., Terada LS., Nwariaku FE., 2011. Regulation of VEGF-induced endothelial cell migration by mitochondrial reactive oxygen species. Am J Physiol Cell Physiol, 301, 695-704.

11. Ushio-Fukai M., Tang Y., Fukai T., Dikalov SI., Ma Y., Fujimoto M., Quinn MT., Pagano PJ., Johnson C., Alexander RW., 2002. Novel role of gp91(phox)-containing $\mathrm{NAD}(\mathrm{P}) \mathrm{H}$ oxidase in vascular endothelial growth factor-induced signaling and angiogenesis. Circ Res, 91, 11601167.

12. Shay KP., Moreau RF., Smith EJ., Smith AR., Hagen TM., 2009. Alpha-lipoic acid as a dietary supplement: molecular mechanisms and therapeutic potential. Biochim Biophys Acta, 1790, 1149-1160.

13. Takaoka M., Ohkita M., Kobayashi Y., Yuba M., Matsumura Y., 2002. Protective effect of alpha- lipoic acid against ischaemic acute renal failure in rats . Clin Exp Pharmacol Physiol, 29, 189-194.

14. Sugimura Y., Murase T., Kobayashi K., Oyama K., Hayasaka S., Kanou Y., Oiso Y., Murata Y., 2009. Alpha-lipoic acid reduces congenital malformations in the offspring of diabetic mice. Diabetes Metab Res Rev, 25, 287-294.

15. Al Ghafli MHM., Padmanabhan R., Kataya HH., Berg B., 2004. Effects of $\alpha$-lipoic acid supplementation on maternal diabetes-induced growth retardation and congenital anomalies in rat foetuses. Mol Cell Biochem, 261, 123-135.

16. Placer ZA., Cushmann LL., Johnson BC., 1966. Estimation of products of lipid peroxidation (as malondialdehyde) in biochemical systems. Anal Biochem, 16, 359-364.

17. Ejerblad E., Fored CM., Lindblad P., Fryzek J., Dickman PW., Elinder CG., McLaughlin JK., Nyren O., 2004. Association between smoking and chronic renal failure in a nationwide populationbased case-control study. J Am Soc Nephrol, 15, 2178-2185.

18. Mercado C., Jaimes EA., 2007. Cigarette smoking as a risk factor for atherosclerosis and renal disease: novel pathogenic insights. Curr Hypertens Rep, 9, 66-72.

19. Xie X., Liu Q., Wu J., Wakui M., 2009. Impact of cigarette smoking in type 2 diabetes development. Acta Pharmacol Sin, 30, 784-787.

20. Bickerstaff M., Beckmann M.,Gibbons K., Flenady V., 2012. Recent cessation of smoking and its effect on pregnancy outcomes. Aust N Z J Obstet Gynaecol, 52, 54-58.

21. Cooper RG., 2006. Effect of tobacco smoking on renal function. Indian J Med, 124, 261-268.

22. Orth SR., 2000. Smoking--a renal risk factor. Nephron, 86, 12-26.

23. Rahman MM., Laher I., 2007. Structural and functional alteration of blood vessels caused by cigarette smoking: an overview of molecular mechanisms. Curr vasc Pharmacology, 5, 276292

24. Csiszar A., Podlutsky A., Wolin MS., Losonczy G., 
Pacher P., Ungvari Z., 2009. Oxidative stress and accelerated vascula raging:implications for cigarette smoking. Front Biosci, 14, 3128-3144.

25. Fakhruddin S., Alanazi WA., Jackson KE., 2017. Diabetes-induced reactive oxygen species: mechanism of their generation and role in renal injury. J Diabetes Res, 1-30.

26. Şahin E., Demirci T., Gedikli S., 2017. Kronik stres ve böbrek: sıçan modeli üzerinde morfometrik ve histopatolojik çalışma. Sakarya Tıp Derg, 7, 168175.

27. Adedayo AD., Tijani AA., Adeniyi TD., 2011. Histological study of smoke extract of tobacco nicotiana on the heart, liver, lungs, kidney, and testes of male Sprague-Dawley rats. Niger Med J, 52, 217-222.

28. Hultberg B., Isaksson A., Brattström L., Israelsson B., 1992. Elevated urinary excretion of betahexosaminidase in smokers. Eur J Clin Chem Clin Biochem, 30, 131-133.

29. Kumari S., Badana AK., Murali MG., Shailender G., Malla R., 2018. Reactive oxygen species: a key constituent in cancer survival. Biomark Insights, 13, 1-9.

30. Stevens A., Lowe J., 2005. Human Histology. 3rd ed., 232, Elsevier Mosby Publication, Philadelphia.

31. Hayman SR., Leung N., Grande JP., Garovic VD., 2012. VEGF inhibition, hypertension, and renal toxicity. Curr Oncol Rep, 14, 285-294.

32. Cha DR., Kim NH., Yoon JW., Jo SK., Cho WY., Kim HK., Won NH., 2000. Role of vascular endothelial growth factor in diabetic nephropathy. Kidney Int, 58, 104-112.

33. Whittle C., Gillespie K., Harrison R., Mathieson PW., Harper SJ., 1999. Heterogeneous vascular endothelial growth factor (VEGF) isoform mRNA and receptor mRNA expression in human glomeruli, and the identification of VEGF148 mRNA, a novel truncated splice variant. Clin Sci, 97, 303-312.

34. Dvorak HF., 2001. Vascular permeability factor/vascular endothelial growth factor: a critical cytokine in tumor angiogenesis and a potential target for diagnosis and therapy. J Clin Oncol, 20, 4368-4380.

35. Heeschen C., Jang JJ., Pathak A., Kaji S., Hu BS., Tsao P., Johnson F., Cooke JP., 2001. Nicotine is an agent of angiogenesis: a pathophysiological link to cancer and atherosclerosis. Nat Med, 7, 833-839.

36. Conklin BS., Zhao W., Zhong DS., Chen C., 2002. Nicotine and cotinine up-regulate vascular endothelial growth factor expression in endothelial cells. Am J Pathol, 160, 413-418.

37. Ushio-Fukai M., Alexander RW., 2004. Reactive oxygen species as mediators of angiogenesis signaling:role of $\mathrm{NAD}(\mathrm{P}) \mathrm{H}$ oxidase. Mol Cell Biochem, 264, 85-97.

38. Kaner RJ., Ladetto JV., Singh R., Fukuda N., Matthay MA., Crystal RG., 2000. Lung overexpression of the vascular endothelial growth factor gene induces pulmonary edema. Am J Respir Cell Mol Biol, 22, 657-664.

39. Brausewetter F., Jehle PM., Jung MF., Boehm BO., Brueckel J., Hombach V., Osterhues HH., 2001. Microvascular permeability is increased in both types of diabetes and correlates differentially with serum levels of insulin-like growth factor I (IGF-I) and vascular endothelial growth factor (VEGF). Horm Metab Res, 33, 713-720.

40. de Vriese AS., Tilton RG., Elger M., Stephan CC., Kriz W., Lameire NH., 2001. Antibodies against vascular endothelial growth factor improve early renal dysfunction in experimental diabetes. J Am Soc Nephrol, 12, 993-1000.

41. Veron D., Reidy KJ., Bertuccio C., Teichman J., Villegas G., Jimenez J., Shen W., Kopp JB., Thomas DB., Tufro A., 2010. Overexpression of VEGF-A in podocytes of adult mice causes glomerular disease. Kidney Int, 77, 989-999.

42. Schrijvers BF., Flyvbjerg A., Vriese AS., 2004. The role of vascular endothelial growth factor (VEGF) in renal pathophysiology. Kidney Int, 65, 20032017.

43. Krueger JK., Rohrich RJ., 2001. Clearing the 
smoke: The scientific rationale for tobacco abstention with plastic surgery. Plast Reconstr Surg, 108, 1063-1073.

44. Kiral F., Ulutas PA., Fidanci UR., 2008. Lipid peroxidation and antioxidant enzymes in rats exposed to cigarette smoke. Ankara Üniv Vet Fak Derg, 55, 145-148.

45. Phaniendra A., Jestadi DB., Periyasamy L., 2015. Free radicals: properties, sources, targets, and their implication in various diseases. Indian J Clin Biochem, 30, 11-26.

46. Çakır T., Polat C., Baştürk A., Gül M., Aslaner A., Durgut H., Şehirli AÖ., Aykaç A., Bahar L., Sabuncuoglu MZ., 2015.The effect of alpha lipoic acid on rat kidneys in methotrexate induced oxidative injury. Eur Rev Med Pharmacol Sci, 19, 2132-2139. 